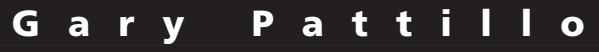

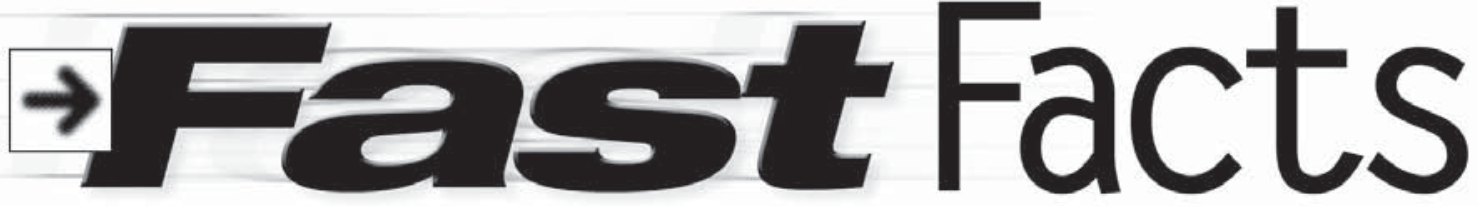

\section{E-mail archives}

At the end of the current eight-year U.S. presidency, the White House is expected to submit more than 100 million e-mail messages to the National Archives. President Clinton's White House submitted only 32 million by the end of his term. According to Kenneth Thibodeau, director of the Electronic Records Archives Program, the growth in electronic records has been about 100 times greater than the increase in paper records over the last decade. "The Archives recently awarded Lockheed Martin Corp. a \$308 million, six-year contract to work on creating a system for saving and accessing electronic data over time."

Anne Marie Squeo, "Oh, has Uncle Sam got mail," Wall Street Journal, December 29, 2005; Page B1. online.wsj.com/ public/article/SB113581938626033499.html. December 29, 2005

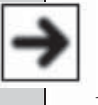

\section{Doctorates and work}

Among doctorate holders, in households with children, women declared shorter work weeks than did men who had the same number of children. In households with no children, women and men work equal numbers of hours. Educators averaged 50.6 hours of work for the week, while those in industry averaged 47.6 hours. Biologists and agricultural scientists work the most hours, averaging 50.53 hours, while those in the social sciences reported an average 48.8 hour work week.

Thomas B. Hoffer and Karen Grigorian, "All In a Week's Work: Workweeks of Doctoral Scientists and Engineers," National Science Foundation, Division of Science Resources Statistics. NSF 06-302, December 2005 www.nsf.gov /statistics/infbrief/nsf06302/. January 3, 2006

\section{Federal spending in academe}

Federal funds for nonmilitary research will rise slightly, according to the American Association for the Advancement of Science, but probably not enough to keep up with the rate of inflation. Spending for most federal programs that support academic research will fall, in real terms, compared with 2005. Several studentaid programs will also get their largest reductions since 1982. The maximum Pell Grant award will remain the same, at $\$ 4,050$, for the fourth year in a row.

Jeffrey Brainard, "Federal Spending: Academe Faces First Real Cuts in 2 Decades," Chronicle of Higher Education, Volume 52, Issue 18, Page A10. January 6, 2006. chronicle.com/weekly/v52/i18/18a01001.htm. January 6, 2006

\section{$\rightarrow$ Baby boomer projections}

In 2006, 7,918 Americans will turn 60 each day, according to projections. That amounts to 330 every hour. In 2030, 57.8 million baby boomers will be alive, 54.9 percent of whom will be female. That year, boomers would be between the ages of 66 and 84 .

U.S. Interim Projections by Age, Sex, Race, and Hispanic Origin," U.S. Census Bureau, Population Division, Population Projections Branch. www.census.gov/ipc/www/usinterimproj/. December 30, 2005

\section{Green campuses}

"Nationwide, more than 110 colleges have built or are building structures certified by the United States Green Building Council, a nonprofit group that promotes construction and designs that meet high standards of energy efficiency." New "green" buildings are saving colleges up to 40 percent in electricity costs. Timothy Egan, "The Greening of America's Campuses," New York Times, Education Life Supplement; Pg. 20, January 8, 2006. www.nytimes.com/2006/01/08/education/edlife/egan_environment.html. January 8, 2006

Gary Pattillo is reference librarian at the University of North Carolina-Chapel Hill, e-mail: pattillo@refstaff. lib.unc.edu 